\title{
Intrahepatic Bile Duct Cancer Pathologic Distant Metastasis TNM Finding v7
}

National Cancer Institute

\section{Source}

National Cancer Institute. Intrahepatic Bile Duct Cancer Pathologic Distant Metastasis

TNM Finding v7. NCI Thesaurus. Code $C 90198$.

A pathologic finding about one or more characteristics of intrahepatic bile duct cancer, following the rules of the TNM AJCC v7 classification system as they pertain to distant metastases. There is no pathologic Mo for intrahepatic bile duct cancer. 